\title{
The Ancestral Heritage: Sundanese Traditional Houses Of Kampung Naga, West Java, Indonesia
}

\author{
Tessa Eka Darmayanti ${ }^{1, a}$ \\ ${ }^{1}$ Interior Design Department, Art and Design Faculty, Maranatha Christian University, Bandung, West Java, Indonesia
}

\begin{abstract}
Sundanese are the largest indigenous ethnic group in the western part of Java Island. Sundanese culture closely relates to Animist, Hindu-Buddhist, and Islam philosophies. It led to the unique creation of the Sundanese traditional houses called Rumah Adat in Kampung Naga where the ancient tradition from their ancestor were upheld until today. Kampung Naga was listed as one of the Sundanese traditional villages known as Kampung Adat in West Java. This village has its own characteristics which enable the conveyance of tremendous tradition from the past, since the reign of Padjajaran Kingdom to the present. Additionally, it has the ability to accelerate globalization of culture these days. The objectives of this paper are to reintroduce and observe the in-depth meaning of Sundanese traditional houses within Kampung Naga. This paper employed qualitative investigation with the support of exploratory literature review. The result of this study portrayed that Sundanese traditional village are depicted as sacred spaces when the founder, the belief, and the nature spirit are interrelated. Thus, the creation of traditional houses in Kampung Naga does not only serve as shelters, but it also has "breath", "soul" and may embody cosmological value. This paper is prominent in the documentation of Sundanese traditional buildings as one of cultural identity of Indonesia, which will deliver the cultural knowledge to the world wide.
\end{abstract}

\section{Introduction}

Animism is one of the earliest beliefs in Indonesia, which respects nature and believes everything in nature to have spirit and power. However, since the coming of various foreign nations to this country to spread their faith through their cultures, the Indonesian people started to believe in God. Animism, Hindu-Buddhist and Islam philosophies influenced the Sundanese culture and fused into various aspects of life, including buildings (traditional houses). Traditional houses known as Rumah Adat are the buildings that may represent expressions of culture. The embodiment of traditional houses becomes a very important issue in traditional community, since it allows the community to show their existence. Looking at that importance, this paper focuses in Sundanese community in Kampung Naga.

In the fourth century, when Hindu Kingdom was ruled in the west part of Java Island, known as Sundanese region, they believe the kingdom as the cosmological center. However, prior to the time when animism became the only belief in primordial era, Sundanese people believe that the houses is the center of their cosmos. A cosmos is an orderly-harmonious system, whereas the Sundanese cosmos itself is called as cosmological mythic-spiritual culture, since it always contains the theological thought [1]. The Sundanese Traditional house has an unseen "energy" that moves both vertically and horizontally, inside and also outside. They have a purpose to connect three different cosmological worlds, upper world (Dunia Atas), middle world (Dunia Tengah) and under world (Dunia Bawah), which will be discussed in the next chapter.

\section{Methodology}

Sundanese culture has existed for more than 15 centuries, it becomes one of ancient cultures in Indonesia, especially West Java. Animist, Hindu-Buddhist as earlier beliefs, is then followed by Islam, which closely relates to the existence of Sundanese Traditional Villages, especially in Kampung Naga. This research employed exploratory qualitative investigation with the support from a list of literature on Sundanese culture and on Kampung Naga. The process of identifying the research framework was based on an observation to the actual site, Kampung Naga that is located between the sacred forest and the river Ciwulan in Tasikmalaya, West Java. In addition, it also implements the approach of cultural studies. This approach assists in the disclosure of philosophies and cosmological meaning of the Sundanese culture in the elements of architecture and interior design of Kampung Naga's rumah adat.

\footnotetext{
a tessaeka82@gmail.com
} 


\section{Sundanese Culture and The History of Kampung Naga}

Parahyangan is known as an old Sundanese name. The Dutch colonists who controlled the area for several centuries rendered the name into Preanger and today it is called Priangan [2]. After the fall of Padjajaran Kingdom in the $16^{\text {th }}$-century, the Sundanese or Urang Sunda (Urang means people, Sunda means Sundanese) had lost their powerful cultural and spiritual center. The absence of a powerful culture center does not mean Sundanese culture disappear. This can be reflected in the presence of Kampung Naga as Sundanese traditional village (Fig.1). The people of Kampung Naga strongly believe the noble values that their ancestors already taught, therefore the ancient traditions are still preserved and actualized in everyday life to present day. Since the rebellion of DI/TII (local community led by Karto Suwiryo), the worst tragedy had happened in 1956. Kampung Naga had no written manuscript because DI/TII people burnt not only all documents, but also the whole village. After 1956, the people of Kampung Naga try to rebuild the village with their memory without losing their identity [3], since then the history of Kampung Naga is mostly maintained by oral tradition - language. Language becomes a strong tool for Sundanese people.This statement is supported by Memed Sastrahadiprawira, a well-known Sundanese intellectual of the time, expressing it in Sundanese language as follow:

"basa teh anoe djadi loeloegoe, pangtetelana djeung pangdjembarna tina sagala tanda-tanda noe ngabedakeun bangsa pada bangsa. Lamoen sipatna roepa-roepa basa tea leungit, bedana bakat-bakatna kabangsaan oge moesna. Lamoen ras kabangsaanana soewoeng, basana eta bangsa eta oge lila-lila leungit [4]".

Translation:

"The language forms a norm: the most evident and the most comprehensive symbols to distinguish one ethnic group from another. If the characteristics of a language disappears, the distinguishing features of an ethnicity will fade away as well. If an ethnicity no longer exists, the language of the ethnic group will also disappear in due course of time [5]".

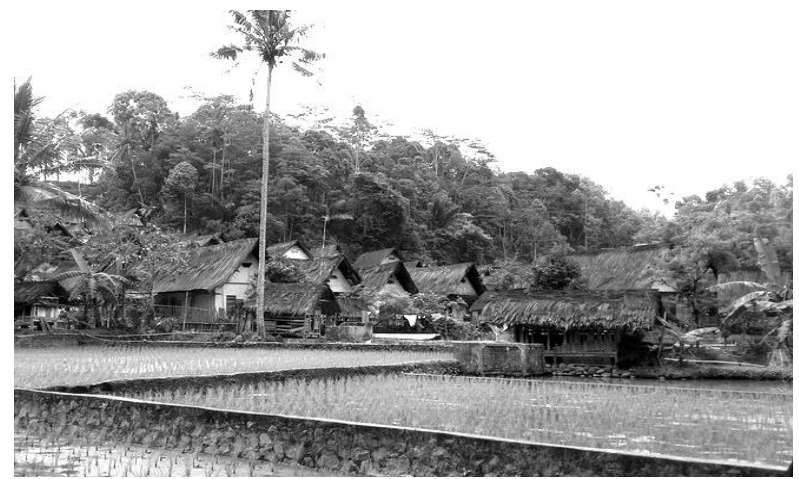

Figure 1. Sundanese Traditional Village: Kampung Naga.

Sundanese villages tend to be a close grouping of houses, usually built on the mountainside. The village is surrounded by wet and dry fields, lying either in the oxbow of a river or in the sacred forest known as hutan keramat or hutan larangan [6] In the forest lies the grave of the village's ancestors called nenek moyang and a place where the spirits of nature are concentrated [7][8]. In Sundanese culture, the universe is divided into three parts based on the most ancient Sundanese cosmological concept called the third pattern, in Sundanese language known as tritangtu. This terminology means "tilu nya hiji, hiji nya tilu", three in one, one in three. Tritangtu may apply in Kampung Naga area. Based on it the Sundanese world are divided into three parts, known as Buana Larang - Dunia Bawah (under world), Buana Panca Tengah - Dunia Tengah (middle world) and Buana Nyungcung - Dunia Bawah (upper world). Dunia Bawah in Kampung Naga consists of field, fishpond, rice field and saung lisung - a space where rice is husked. Houses, mosque, gathering building or Bale Patemon, granaries called leuit and sacred houses known as Bumi Ageung are placed in the middle world. The upper world is the space for the grave of Eyang Singaparna who is believed as the ancestor of Kampung Naga [9]. The term of tritangtu is derived from Sanskrit, tan means spider web. In the holistic perspective, tritangtu can be seen as one of networking that expands outside but strongly fuses inside. Tritangtu is known as the basic concept of Sundanese life. The concept was born based on primordial farmers' thought. They believe everything in this world is always connected to something opposite or dualistic. To avoid the conflict, thus the third principle was born to balance it and became one harmony. Dualistic becomes trinity thought [1]. This trinity concept becomes the theoretical framework to analyze the relation between rumah adat in Kampung Naga and cosmology.

\section{Discussion: The Traditional Houses of Kampung Naga}

House in Sundanese is called in various names such as bumi, imah or rorompok. Bumi can also mean world, earth, globe or territory. Interestingly, the number of house in Kampung Naga cannot be extended. Based on the interview with Mr. Cahyan in January 2016, he said that Kampung Naga consists of 113 buildings, including the traditional houses, sacred house called Bumi Ageung, 
the mosque, and the gathering building. If there are any new family members who do not have any inheritance from their parent, it is possible for them to build a house outside the traditional village. Additionally, they have other unique tradition about the house position. All buildings' main doors always face either south or north side and that the second door must be in the same side. This door is usually near to the kitchen area. Placing doors in the opposite walls are forbidden, as well as when all buildings face the east.

The type of Kampung Naga house is called rumah panggung with julang ngapak roof type (Fig 2). The shape of "capit" above the roof may represent both male and female [1].

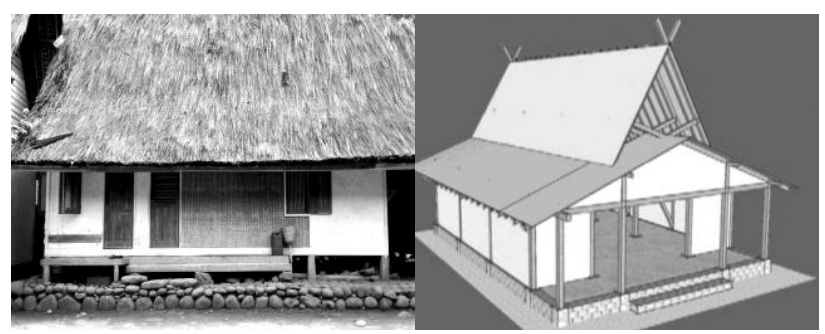

Figure 2. Kampung Naga Traditional House (left) and Julang Ngapak (right).

Initially, Kampung Naga houses do not have any window and provide one door only. However, after 1956, the house has had window and two doors. Kampung Naga house is built by natural material. For them, life is not in nature but it is to live with nature [9]. It is Pamali or taboo to use other materials except those from the nature. It means that it is against the ancestors' tradition. Based on the house position resting on large stone plinths or called umpak, either natural or man made umpak, the posts are elevated to $40 \mathrm{~cm}$ above the ground or higher. The walls are traditionally made of two types of plaited bamboo matting, called bilik kepang and bilik sasag. The floors are made of wooden planks, whereas the ceiling are also made of bilik kepang. The frame of the roof assembly is made of bamboo and timbers covered by injuk and wild plant that locally known as daun tepus.

Traditional house in Kampung Naga not only serves as living space, but it also has philosophical value both vertically and horizontally. Vertical meaning represents the relationship between man and God, whereas horizontal meaning is about interactions among human being and nature. The culture in Kampung Naga retains many ceremonies. Based on interview with Mr. Cahyan, there is ceremony before building a new house called Ngajarah Bumi. It should provide sesajen, the ritual when chicken's head and herbs are buried in the middle of the house that will be built. This is aimed at giving salvation to the land and the nature spirits during the construction. Another ceremony known as Salametan Bumi. It is the ceremony after completing the house in order to assure harmony and good fortune. There are explanation about Salametan Bumi, expressing it in Sundanese statement "saatos bumi beres, kedah aya syukuran, nyayagikeun kupat, dupi sareng tumpeng isi koneng. Bumi nu tos janten di doakeun ku pemangku adat teras bumi dipasang kale sareng sawen, janten tolak bala." The statement means after the house is ready to inhabit, the household should offer syukuran or salametan, salametan is communal feast that provides meal. The kuncen will bless the house with jajampe (invocation or a prayer muttered over anything in order to produce some beneficial result), at the same time he gives kale and sawen as a ritual of tolak bala. Tolak bala is known as ritual activities aimed at avoiding something troublesome which may come through the involvement of a spirit, as well as some misfortune happening to a person or the community [10]. Usually, kale that is made from bamboo will be put in every corner of the house and sawen, the combination of leaf and grass, will placed in the front door [11].

Vertically, traditional house is divided into three spaces. The attic known as para, the ceiling called lalangit, and the space under the house called kolong or kokolong. The space between lalangit and kokolong is the actual house called bumi or imah. Horizontally, the house is divided into five areas (Fig 3.) - tepas (man territory) also known as guest reception room, pawon or kitchen, and rice storage called goah as female territory (Fig.4), tengah imah has similar function to family room and bedroom known as pangkeng.

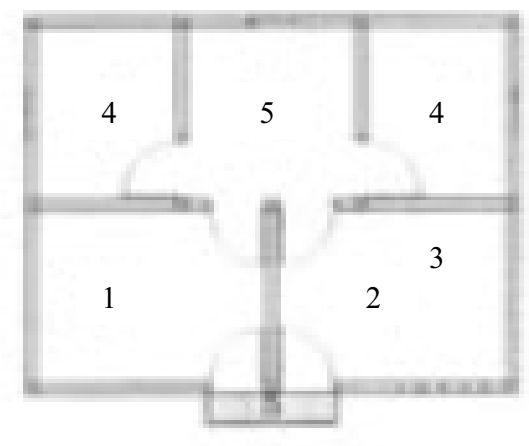

1 Tepas

(Man territory)

2 Pawon

(Kitchen)

3 Goah

(Rice storage)

4 Pangkeng

(Bedroom)

5Tengah Imah

(Family room)

Figure 3. The Layout of Traditional House.
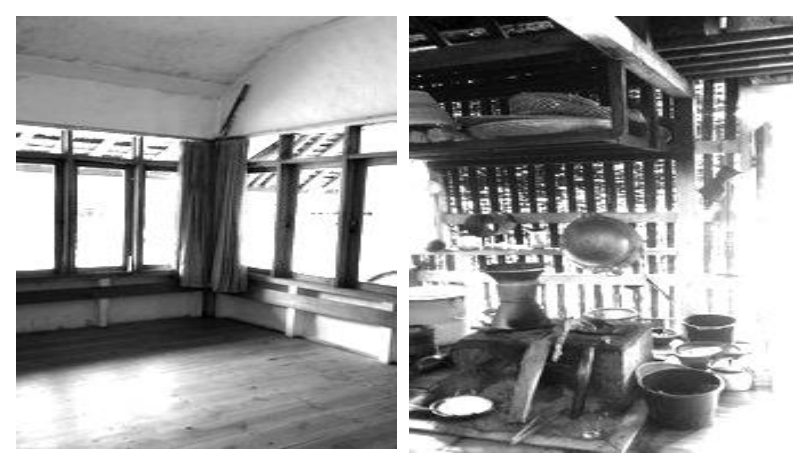

Figure 4. Tepas as a Man Territory (left) and Pawon as a Female Territory (right)

In Sundanese culture, female has special space that she can represent particular life, becoming "the content/isi" for human's life circle in a house. House is considered as place or "container/wadah" of life. In Sundanese culture, the terms "isi" and "tempat" relate closely to "Dunia Atas" and "Dunia Bawah" as parts of the Sundanese cosmology. It can be better understood using the 
approaches of poetry meaning or Sundanese ancient verse containing the meaning of Sundanese cosmology.

Earlier in this writing, it has been explained that ancient Sundanese people are included in the farmer category, therefore rice field and farmers are important for Sundanese society. This kind of rice (padi) relies heavily on rainfall, therefore the existence of the "Dunia Atas" are significantly important. In Sundanese culture, the Upper World is known as wet areas that are identical with sky, which has the nature of female, whereas the Under World is known as dry areas that are identical with land, which has the nature of male. The division of world based on that concept of gender can be seen in Sundanese verse. The Sundanese verse is a an epic story that rhymes. It tells the story of Kings or Princes from Galuh or Padjadjaran Kingdom. Commonly, the verse is recited with the accompaniment of Sundanese traditional music instrument, Kecapi. The followings are 12 line verse that is divided into two. They tell the story of Raden Layung at Panggung Karaton [12]:

\section{A}

Teras kangkung galeuh bitung

Tapak meri dina leuwi

Tapak soang dina bantar

Tapak sireum dina batu

Kalakay pare jumarum

Sisir serit tanduk ucing

According to Jakob Sumardjo (2015), there are contradictions in meaning between part $\mathrm{A}$ and $\mathrm{B}$, however if one of the part is reversed, then the meaning looks complementary. The verse could be seen as follows:

A

Sisir serit tanduk ucing Tapak Sisir badag tanduk kuda Kalakay pare jumarum Kekemben layung kasunten Tapak sireum dina batu Kurambuan kuwung-kuwung Tapak soang dina bantar Tulis langit gurat mega Tapak meri dina leuwi Panjangnya sabudeur jagat Teras kangkung galeuh bitung Inten sagede baligo

The critical interpretations of the poetry are as follows:

\section{A}

Sisir serit tanduk ucing Tapak (as plural symbol, represent wordliness)

Kalakay pare jumarum (pare means dried rice, down to earth in nature, represent male)

Tapak sireum dina batu
Sisir badag tanduk kuda (as singular symbol, represents heavenly nature)

Kekemben layung kasunten (layung means twilight, high in nature, like sky, represents women)

Kurambuan kuwung-kuwung (kurambun means rainbow, high in nature, like sky)
Tapak soang dina bantar

Tulis langit gurat mega (tulis langit means writing in the sky, high in nature, like sky)

Tapak meri dina leuwi (tapak means foot print, down to earth in nature )

Panjangnya sabudeur jagat (sabundeur jagat means around the sky)

Teras kangkung galeuh bitung Inten sagede baligo (Inten (it means "empty/kosong", means diamond, baligo or represent "wadah" or beligo means watermelon container) diamond as big as watermelon), it means "content/isi")

\subsection{Cosmological Value of The Traditional House}

Why do houses in Kampung Naga become the center of "universe"? This can be answered using the analysis of tritangtu approach saying that house is divided into three parts; The Upper World (Buana Nyungcung), The Middle World (Buana Panca Tengah), and The Under World (Buana Larang) (Fig 5).

In the earlier section of Introduction, it is said that Sundanese Traditional house is considered as the central cosmos for Sundanese daily activities. This house can be said as the microcosmos or macrocosmos within the Sundanese culture. This is the center of "universe" for the surrounding environments, it gives "contents" for "emptiness". These terms can be identified from the concept of birth of the three patterns or tritangtu, which is known as the Sundanese philosophy.

In the process of tritangu emergence, every entity starts with "emptiness", then "content" is created. In Sundanese culture, dominated by the belief of Animism and Hinduism, it is believed that "emptiness" creates willingness known as tekad. Kuasa (power) relates closely to power known as ucap and to deed known as lampah. Those three philosophies are the modern terminology for Batara Keresa, Batara Kawasa, and Batara Karana. They are the nature or characteristics of Batara Tunggal or Sang Rama, where in Islamic approach is called as Adam Tunggal. Those natures are the "contents" for the "emptiness" [13].

The existence of house is started with emptiness. The potential of willingness, power, and deed creates the division of interior spaces to provide facilities for the inhabitants. The house becomes the macrocosmos for the inhabitants whose natures are microcosmos. The inhabitants unite with "the contents" that has been created into unity. The natures of the house change into microcosmos when the inhabitants leave the house. They switch position with the inhabitants as the macrocosmos, and therefore the house returns to become the center of cosmos for the surroundings. 


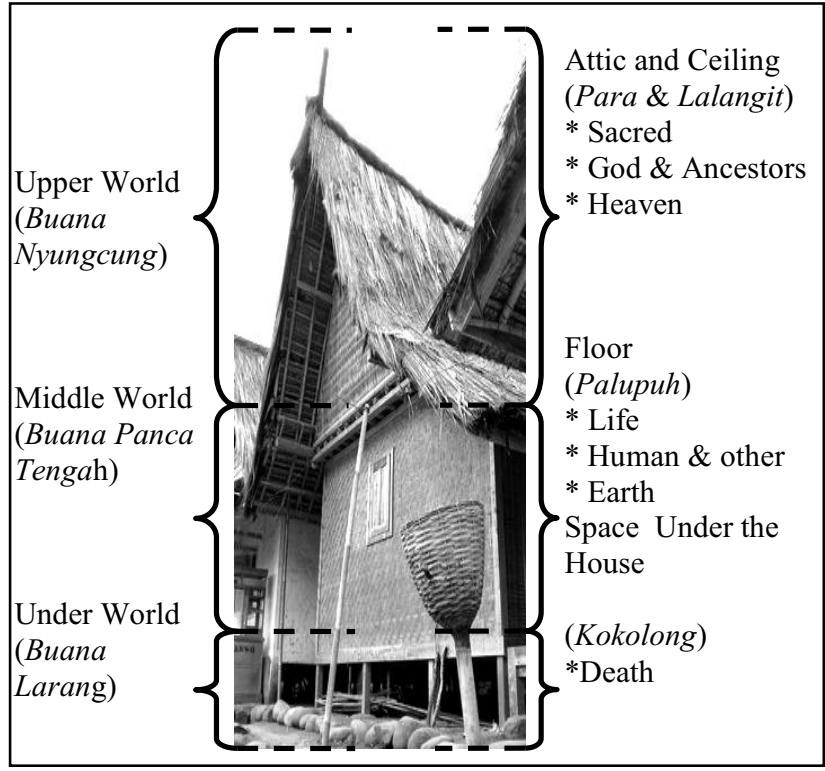

Figure 5. Kampung Naga Traditional House Based on The Universe Level

\section{Summary}

The people of Kampung Naga has to deal with globalization, they succeed sustaining their identity with unique traditions that consist of marvelous rituals and ceremonies, especially in building a house. They believe the Rumah Adat has not only in-depth meaning beyond the physical form, but also reflects the "wider" world. It also represents the harmonious relationship between human, nature, and their communication with God as the divine power. Many research discuss Sundanese traditional house in Kampung Naga. However, this paper is expected to give contribution by proposing in-depth analysis on the traditional house with cosmological approach called tritangtu, as the basic of ancient Sundanese principle cosmology. This paper may also be a reference for future research with more in-depth analysis.

\section{References}

1. Sumardjo, Jakob, Sunda: Pola Rasionalitas Budaya. Bandung, Kelir, (2015)

2. Spiller, Henry, Erotic Triangles: Sundanese Dance and Masculinity in West Java. Chicago, The University of Chicago Press, (2010).

3. Maria, Siti; Rosyadi; Indrawati, Dewi; Astuti, Renggo, Sistem Keyakinan Pada Masyarakat Kampung Naga Dalam Mengelola Lingkungan Hidup - Studi Tentang Pantangan dan Larangan, Jakarta, Departement Pendidikan dan Kebudayaan RI, 20 (1995)

4. Sastrahadiprawira, Memed, Jodo Pakokolot, 99 (1929)

5. Moriyama, Mikihiro, Sundanese Print Culture and Modernity in 19th-century West Java. Singapore: Singapore University Press, (2005)
6. Wessing, Robert, Constituting the world in the Sundanese house in Indonesian Houses: Volume 2: Survey of Vernacular Architecture in western Indonesia. Leiden: KITLV Press, (2008)

7. Ganda, Yahya, Arsitektur Tradisional Daerah Jawa Barat. Bandung: Proyek Inventarisasi dan Dokumentasi Kebudayaan Daerah, Direktorat Sejarah dan Nilai Tradisional, Direktoral Jenderal Kebudayaan, Departement Pendidikan dan Kebudayaan, 12 (1983)

8. Atmowiloto, Arswendo, Indonesia from The Air. Jakarta, Humpus. Singapore, Times, 102 (1986)

9. Hermawan, Iwan, Bangunan Tradisional Kampung Naga: Bentuk Kearifan Warisan Leluhur Masyarakat Sunda. Jurnal Sosio Didaktika, Vol. 1, No.2, 141-150 (2014)

10. Yousof, Ghulam-Sarwar, One Hundred and One Things Malay. Singapore: Partridge publishing, (2016)

11. Personal Interview with Mr. Cahyan, 9-10 January 2016 and 17-18 January 2016, Local People of Kampung Naga.

12. Rosidi, Ajip, Panggung Karaton, Project Research of Sundanese Poem and Folklore, Bandung, (1971)

13. Sumardjo, Jakob, Estetika Paradoks. Bandung, Kelir, 172 (2014) 